\title{
Portfolio Assessment for Improving Unnes Students' English Speaking Ability
}

\author{
Intan Permata Hapsari ${ }^{1}$, Fahrur Rozi ${ }^{2}$, Lulu April Farida ${ }^{3}$, Rahmi Nur Baity Wahyuni ${ }^{4}$ \\ \{intan74@mail.unnes.ac.id ${ }^{1}, \underline{\text { frozi@mail.unnes.ac.id }}{ }^{2}, \underline{\text { lulu.farida@mail.unnes.ac.id }}{ }^{3}$ \} \\ Language and Arts Faculty,Universitas Negeri Semarang ${ }^{1}$, Economic Faculty, Universitas Negeri \\ Semarang ${ }^{2}$, Sport Science Faculty, Universitas Negeri Semarang ${ }^{3}$
}

\begin{abstract}
This study aimed at finding out the role and effectiveness of portfolio assessment in improving students' English speaking skill. This exploratory research employed a mixed-method approach, and 175 students from 8 faculties in UNNES participated in this study. The researchers acquired the data through observation, lecturer/journal notes, and learning achievement tests. During the four separate phases, there were increase in students' speaking, i.e. the $1^{\text {st }}$ and $2^{\text {nd }}$ daily score, the mid-term and final semester score. Improvements were also made on the five aspects of English speaking performance: fluency, pronounciation \& accent, vocabulary, grammar, and detailed information. In summary, portfolio assessment improved students' speaking learning process and highly effective for students' English speaking skill improvement as they can see the scores by themselves hence they can measure their own progress. Portfolio assessment also potentially improves lecturers' ability in assessing students' speaking performance and increase student's participation and attention towards the learning process.
\end{abstract}

Keywords: assessment, portfolio, speaking ability

\section{Introduction}

Among the four English skills taught namely listening, speaking, reading and writing, this study focused on students' English speaking ability. The students' speaking ability were minimal and disappointing, this was caused by many factors including the type of assessment in the teaching and learning process.

As an essential component in learning process, assessment of learning outcomes can measure the success of learning. Assessment findings are also important for improving learning. Learning outcomes and students' learning process need to be evaluated hence it needs to be thoroughly assessed. Teachers need choose a comprehensive assessment technique as learning outcomes assessment is an integral part of learning process. Learning outcomes evaluation aims to measure the achievement of predetermined basic competencies. This measurement could use various assessment techniques in the learning and teaching activities. Students' ability to build and reflect upon an assignment or work can be measured through portfolio assessment, thus portfolio assessment was chosen as an alternative to improve UNNES students' English speaking skill. Portfolio assessment involves collection of relevant materials related to the goals set by students during the learning process. 
Portfolio has emerged as a viable assessment tool since 1990s, portfolio assesses a student's best collection of work. It is not only documenting the learner's progress over time, but also encouraging them to become more independent to be directed, taking initiative to learn, making assessments, participating in their own evaluation/work, and solving problems [1]. Portfolio as a form of physical object or a collection of results (evidence) of an activity, or a bundle, which is a set of students' documentations or work results stored in a bundle. For example, a bundle of student work results from initial tests, assignments, anecdotal notes, award certificates, structured assignment information, to final tests. This portfolio is a collection of selected works from a student or a group of students [2]. Portfolio assessment is a continuous process (continuous assessment), that charts student progress toward the expected standards in each learning outcome. For each candidate to benefit from continuous assessment, the portfolio supervisor should have regular review sessions to discuss assessments with students and monitor student progress towards curriculum learning outcomes [3]. Portfolio assessment is an approach or assessment model that aims to measure students' ability in building and reflecting an assignment or work by collection relevant materials to the goals and desires set by the students, so that the results of the work can be assessed and commented by the teacher within a certain period [4].

Portfolio can be divided into two types; process and product. Process portfolio shows learning activities to achieve competency standards, basic competencies, and a set of indicators required by the curriculum, and shows all the results from the beginning to end within a certain period of time. While product portfolio only emphasizes mastery (material) of the tasks required in competency standards, basic competencies, and a set of indicators for the achievement of learning outcomes, and shows the best evidence, regardless of how and when the evidence is obtained. Examples of product portfolio are show portfolio and documentary portfolio [5].

This study aims to identify the role as well as to find out the effectiveness of portfolio assessment in improving students' English speaking ability. Theoretically, the researchers expect that the findings in this study give a broader insight regarding theories used in research and portfolio assessment implementation in improving students' English speaking ability. Pedagogically, this research stages improve lecturers, assessment developers, and teachers in the implementation of portfolio assessment to improve students' English speaking ability. Practically, by understanding the stages, from the results of this study, lecturers, assessment developers, and teachers are able to apply portfolio assessment to improve students' English speaking ability.

\section{Methods}

This research was conducted on the students at Language and Non-Language Faculties, including: Faculty of Languages and Arts, Faculty of Economics, Faculty of Sport Sciences, Faculty of Engineering, Faculty of Law, Faculty of Education, Faculty of Mathematics and Natural Sciences, and Faculty of Social Sciences. 175 students were analysed as samples. This research used Mixed Methods. There are four types of Mixed Methods research approach. They are embedded, explanatory, exploratory, and triangulation. In this study, the researchers used exploratory design, where this type of research was carried out by implementing qualitative research first then followed by quantitative research. The qualitative method was used to answer the first problem statement, which was "How is the implementation of portfolio assessment in improving students' English speaking ability". Meanwhile, the quantitative method was used to answer the second problem statement, which was "How effective is the implementation of 
portfolio assessment in improving students' English speaking ability". The following are the stages of Mixed Methods research

Figure 1 Exploratory Type Design [6]

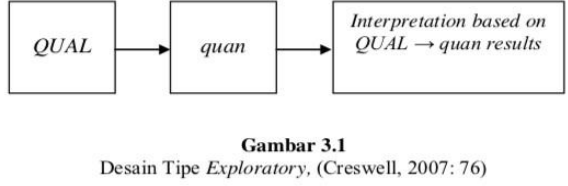

The indicators of success in this study are: a) at least $75 \%$ of students scored above $70, b$ ) $75 \%$ of students actively speak English in the lecturing process, c) $75 \%$ of students actively speak English in group discussions. The data sources were 175 students from Faculty of Languages and Arts, Faculty of Economics, Faculty of Sport Sciences, Faculty of Engineering, Faculty of Law, Faculty of Education, Faculty of Mathematics and Natural Sciences, and Faculty of Social Sciences. The data collection techniques used in collecting primary and secondary data were:

1. Observation guideline: direct observation of learning English with portfolio assessment technique.

2. Checklist for document: observation sheets, learning assessment sheets, quiz or learning achievement tests, and lecturer/journal notes.

The stages in data analysis include: data reduction, data presentation, and conclusion [7]. Data reduction is the process of selecting, simplifying, abstracting and transforming raw data from written notes in the field to a complete final report. Compilation of data is a collection of information arranged in order to provide the possibility to make conclusion. In presenting the data, it was carried out after reducing the data that were used as report material. Making conclusion or verification in the form of a keynote of data presentation which is the analysis result carried out in the research. Initial conclusion that is not yet completely mature or final.

\section{Results}

The results of this study answer two research problem statements, which are the implementation of portfolio assessment in improving English speaking ability and the effectiveness of the portfolio assessment in improving UNNES students' English speaking skill. Working portfolio was used for summative assessment function. English speaking video recordings were used a $\mathrm{s}$ the data. The data were then analysed through an evaluation rubric consisting of fluency, pronunciation and accent, vocabulary, grammar, and details of information. The table below presents the results, categorized by the time of data collection:

Table 1. Students' Achievement. Data of Student Achievement Analysis Results on Daily Score

\begin{tabular}{|c|c|c|c|}
\hline No & Note & Daily Score 1 & Percentage \\
\hline 1 & SCORE $>75$ & 135 students & $77 \%$ \\
\hline 2 & SCORE $<75$ & 40 students & $23 \%$ \\
\hline \multicolumn{2}{|c|}{ TOTAL } & 175 students & \\
\hline
\end{tabular}


Table 2. Students' Achievement. Data of Student Achievement Analysis Results on Daily Score 2

\begin{tabular}{|c|c|c|c|}
\hline No & Note & Daily Score 2 & Percentage \\
\hline 1 & SCORE $>75$ & 140 students & $80 \%$ \\
\hline 2 & SCORE $<75$ & 35 students & $20 \%$ \\
\hline \multicolumn{2}{|c|}{ TOTAL } & 175 students & \\
\hline
\end{tabular}

Table 3. Students' Achievement. Data of Student Achievement Analysis Results on Mid Semester

\begin{tabular}{|c|c|c|c|}
\hline No & Note & Mid Semester Score & Percentage \\
\hline 1 & SCORE $>75$ & 152 students & $87 \%$ \\
\hline 2 & SCORE $<75$ & 23 students & $13 \%$ \\
\hline \multicolumn{2}{|c|}{ TOTAL } & 175 students & \\
\hline
\end{tabular}

Table 4. Students' Achievement. Data of Student Achievement Analysis Results on Final Semester

\begin{tabular}{|c|c|c|c|}
\hline No & Note & Final Semester Score & Percentage \\
\hline 1 & SCORE $>75$ & 159 students & $91 \%$ \\
\hline 2 & SCORE $<75$ & 16 students & $9 \%$ \\
\hline \multicolumn{2}{|c|}{ TOTAL } & 175 students & \\
\hline
\end{tabular}

Observation results of portfolio assessment application on UNNES students' English speaking skill for the first daily score shows that 135 students $(77 \%)$ scored more than 75 while 40 students $(23 \%)$ scored 75 or less. In the second daily score, 140 students $(80 \%)$ scored more than 75 while 35 students $(20 \%)$ scored 75 or less. In the mid-test score, 152 students $(87 \%)$ scored more than 75 while 23 students $(13 \%)$ scored 75 or less. Whereas in the final-test score, 159 students $(91 \%)$ scored more than 75 while 16 students $(9 \%)$ scored 75 or less. Students were observed using evaluation rubric containing fluency, pronunciation and accent, vocabulary, grammar, and details of information. The table below presents the result:

Table 5. Students' Observation Result. Data of Students' English Speaking Ability on Daily Score 1 


\begin{tabular}{|l|c|c|c|c|c|c|}
\hline \multicolumn{1}{|c|}{ Aspect } & \multicolumn{6}{c|}{ Scale of Score } \\
\hline & 1 & 2 & 3 & 4 & 5 & total \\
\hline Fluency & $5.7 \%$ & $28 \%$ & $56.5 \%$ & $9.7 \%$ & $0 \%$ & $100 \%$ \\
\hline Pronunciation and Accent & $6.8 \%$ & $29.1 \%$ & $50.2 \%$ & $13.7 \%$ & $0 \%$ & $100 \%$ \\
& & & & & & \\
\hline Vocabulary & $6.2 \%$ & $22.8 \%$ & $58.2 \%$ & $12.5 \%$ & $0 \%$ & $100 \%$ \\
\hline Grammar & $10.8 \%$ & $17.7 \%$ & $64 \%$ & $7.4 \%$ & $0 \%$ & $100 \%$ \\
\hline Details of information & $6.2 \%$ & $17.7 \%$ & $59.4 \%$ & $16.5 \%$ & $0 \%$ & $100 \%$ \\
\hline
\end{tabular}

Table 6. Students' Observation Result. Data of Students' English Speaking Ability on Daily Score 2

\begin{tabular}{|l|c|c|c|c|c|c|}
\hline \multicolumn{1}{|c|}{ Aspect } & \multicolumn{7}{c|}{ Scale of Score } \\
\hline & 1 & 2 & 3 & 4 & 5 & total \\
\hline Fluency & $5.1 \%$ & $23.4 \%$ & $61.1 \%$ & $10.2 \%$ & $0 \%$ & $100 \%$ \\
\hline Pronunciation and Accent & $6.8 \%$ & $13.7 \%$ & $61.7 \%$ & $17.7 \%$ & $0 \%$ & $100 \%$ \\
& & & & & & \\
\hline Vocabulary & $5.1 \%$ & $16 \%$ & $66.2 \%$ & $12.5 \%$ & $0 \%$ & $100 \%$ \\
\hline Grammar & $5.1 \%$ & $11.4 \%$ & $74.8 \%$ & $8.5 \%$ & $0 \%$ & $100 \%$ \\
\hline Details of information & $5.7 \%$ & $14.8 \%$ & $62.8 \%$ & $16.5 \%$ & $0 \%$ & $100 \%$ \\
\hline
\end{tabular}

Table 7. Students' Observation Result. Data of Students' English Speaking Ability on Mid Semester

\begin{tabular}{|l|c|c|c|c|c|c|}
\hline \multicolumn{1}{|c|}{ Aspect } & \multicolumn{7}{|c|}{ Scale of Score } \\
\hline & 1 & 2 & 3 & 4 & 5 & total \\
\hline Fluency & $4.5 \%$ & $22.2 \%$ & $61.7 \%$ & $11.4 \%$ & $0 \%$ & $100 \%$ \\
\hline Pronunciation and Accent & $5.1 \%$ & $11.4 \%$ & $64.5 \%$ & $18.8 \%$ & $0 \%$ & $100 \%$ \\
& & & & & & \\
\hline Vocabulary & $4 \%$ & $11.4 \%$ & $71.4 \%$ & $13.1 \%$ & $0 \%$ & $100 \%$ \\
\hline Grammar & $4.5 \%$ & $8 \%$ & $76.5 \%$ & $10.8 \%$ & $0 \%$ & $100 \%$ \\
\hline Details of information & $4.5 \%$ & $12.5 \%$ & $64.5 \%$ & $18.2 \%$ & $0 \%$ & $100 \%$ \\
\hline
\end{tabular}

Table 8. Students' Observation Result. Data of Students' English Speaking Ability on Final Semester 


\begin{tabular}{|l|r|c|c|c|c|c|}
\hline \multicolumn{1}{|c|}{ Aspect } & \multicolumn{6}{c|}{ Scale of Score } \\
\hline & 1 & 2 & 3 & 4 & 5 & total \\
\hline Fluency & $3.4 \%$ & $10.2 \%$ & $74.2 \%$ & $12 \%$ & $0 \%$ & $100 \%$ \\
\hline Pronunciation and Accent & $4 \%$ & $9.7 \%$ & $61.7 \%$ & $23.4 \%$ & $1.1 \%$ & $100 \%$ \\
& & & & & & \\
\hline Vocabulary & $3.4 \%$ & $5.7 \%$ & $74.2 \%$ & $16 \%$ & $0.57 \%$ & $100 \%$ \\
\hline Grammar & $4 \%$ & $5.1 \%$ & $77.1 \%$ & $13.7 \%$ & $0 \%$ & $100 \%$ \\
\hline Details of information & $3.4 \%$ & $9.1 \%$ & $66.8 \%$ & $20.5 \%$ & $0 \%$ & $100 \%$ \\
\hline
\end{tabular}

\section{Discussions and Conclusions}

The researchers worked on the obtained data from observation and students learning outcome to suggest the implementation and effectiveness of portfolio assessment in UNNES students' English speaking skill. The increse in students' skill were parted into four phases: The 1st daily, 2nd daily, mid term test, and final test scores. It was proven that the portfolio assessment implementation inluenced students' speaking skill in a positive way.

The results of this study are in line with the previous researches [8], [9], [10] . However, the results of this study contradict to findings a previous research which stated that portfolio assessment only has a positive impact on writing, listening, and reading ability[11]. In evaluation process of these four phases, the researchers assessed students' speaking ability with five aspects consisting of fluency, pronunciation and accent, vocabulary, grammar and details of information. Overall, of the five aspects that became the criteria, most students scored a three point in the four phases, thus there was an increase in each phase. These results are not in line with a previous research where the aspect of pronunciation is the most dominant in the study [11].

The evaluation phase of the first daily score shows that 135 students (77\%) scored more than 75 while 40 students $(23 \%)$ scored 75 or less. There were only a $2 \%$ increase as set on the research target. This means that were still trying to get used to the newly-applied portfolio assessment. Reciprocally, English-speaking ability results were shown on five aspects. The results showed that students scored only 1-3 points on each aspect. On fluency aspect, most of the students $(56.5 \%)$ scored 3 and the rest scored $1(5.7 \%), 2(28 \%)$, and $4(9.7 \%)$. This 3 point score shows that their compassion in speaking has not been too visible. They still have doubts on searching phrases and words to be conveyed. Their voice is unstable or fluctuated while they are speaking. On the aspect of pronunciation and accent, most were scored $3(50.2 \%)$, while the rest scored $1(6.8 \%), 2(29.1 \%)$, and $4(13.7 \%)$. This 3 point score on this aspect indicated that their pronunciation is good enough, but there are problems with pronunciation that make the researchers have to fullyconcentrate upon listening to their speaking. While in the aspect of vocabulary, most also scored $3(58.2 \%)$, while the rest were $1(6.2 \%), 2(22.8 \%)$, and $4(12.5 \%)$. A 3 point score on this aspect shows that the students have limited vocabulary. They still used common vocabularies and often use vocabularies not suitable to the context. On the aspect of grammar, most got 3 point score as much as $64 \%$ while the rest were $1(10.8 \%), 2(17.7 \%)$, and 
4 (7.4\%). They still made several grammatical mistakes, although it did not really affect the meaning. They were also still use monotonous grammar structures. As for the last aspect, which is details of information, most got 3 point score as much as $59.4 \%$, while the rest were $1(6.2 \%)$, $2(17.7 \%)$, and $4(16.5 \%)$. In this aspect, the students were quite detailed in describing the content, but they were still lacking in providing additional information.

On the second daily score evaluation phase, students scored more than 75 were increased by $3 \%$ from the previous phase, exceeding 140 students $(80 \%)$. Students scored 75 or less were $35(20 \%)$. The results of students' speaking ability in five aspects were mostly still scored 3 point. However, speaking skills were both increased and decreased in several aspects. The aspect of fluency, most scored $3(61.1 \%)$. The rest were scored $1(5.1 \%), 2(23.4 \%)$, and 4 $(10.2 \%)$. The increase in speaking skill obtained by the students which mostly scored 3 showed that they have enough fluency in speaking, but they still have doubts and search phrases and words to be conveyed. The aspect of pronunciation and accent were mostly scored $3(61.7 \%)$, while the rest were scored $1(6.8 \%), 2(13.7 \%)$, and $4(17.7 \%)$. The pronunciation and accent of students in this phase were good enough, but they still faced problems with pronunciation because of misunderstandings. Furthermore, the aspect of vocabulary were mostly scored 3 $(66.2 \%)$, while the rest scored $1(5.1 \%), 2(16 \%)$, and $4(12.5 \%)$. Point 3 on this aspect shows that they were still have a limited vocabulary. They still use common vocabularies and often use vocabularies not suitable to the context. The aspect of grammar scored 3 by $74.8 \%$, while the rest were scored $1(5.1 \%), 2(11.4 \%)$, and $4(8.5 \%)$. Students made several grammatical mistakes, but it did not really change the meaning; they also still used monotonous grammar structures. The last aspect is details of information, Scored $3(62.8 \%)$, while the rest were scored $1(5.7 \%), 2(14.8 \%)$, and $4(16.5 \%)$. In this aspect, the students were quite detailed in describing the content, but they were still lacking in providing additional information on the content.

In the third phase, the mid-test score shows positive on implementation and effectiveness of portfolio assessment, as there were increases in mid-test score. It indicates that students learn from their mistakes in the previous phases. There were researches concluding that portfolio has a positive effect that students can correct their mistakes from the previous phases and in the next phase they could minimize their mistakes [13], [14]. The number of students scored more than 75 were $152(87 \%)$ and students scored 75 or less were $23(13 \%)$. Similar to the two previous phases, in this phase, a 3 point score remained the highest point of five aspects of speaking ability assessment which continued to show an increase in percentage. While the 1 point score has the most decline in percentage. The aspect of fluency in this phase is at point $3(61.7 \%)$. Students still hesitate and stop talking because vocabulary limitation. Meanwhile, $4.5 \%$ of students scored 1 point, they have problems in speaking. They stopped speaking and stayed silent while assessment and observations were conducted. The students scored 2 were $22.2 \%$; they still have the same problem as the students who get 1 point. However, the frequency was not as much. They still get 1 and 2 point, which is $11.4 \%$. Students scored 4 point in this third phase, this shows that their speaking skill was quite fluent even though they still face difficulties. Point 3 also has the highest percentage on pronunciation and accent accent, by $64.5 \%$. The rest were scored $1(5.1 \%), 2(11.4 \%)$, and $4(18.8 \%)$. The pronunciation and accent of students in this phase were improved, but they still face problems on pronunciation. Furthermore, the aspect of vocabulary was mostly scored 3 point $(71.4 \%$,) while the rest are scored 1 point $(4 \%), 2$ $(11.4 \%)$, and $4(13.1 \%)$. The most scored point, 3 , on this aspect shows that they still have a limited vocabulary. The aspect of grammar gets 3 point score $(76.5 \%)$, while the rest were 1 point $(4.5 \%), 2(8 \%)$, and $4(10.8 \%)$. Students made several grammatical mistakes but they do not change the meaning. They also still use monotonous grammar structures. The last aspect, details of information gets 3 point score by $64.5 \%$, while the rest scored 1 point (4.5\%), 2 
$(12.5 \%)$, and $4(18.2 \%)$. In this aspect, they are quite capable describing the content, but still lacking in providing additional information.

The last phase is final test score. It is proved that there were positive implementation and effectiveness of portfolio assessment on students' speaking ability. In this phase, the students scored 75 or less were $16(9 \%)$, while those who scored more than 75 were $159(91 \%)$. the 1 point score in this phase got the lowest percentage in every aspect during the research, which only $3.4 \%$ in the aspect of fluency, vocabulary, and details of information. While in the aspect of pronunciation and accent and grammar, the 1 point score were only $4 \%$. This result showed that few of them have severe pronunciation and it makes their listeners do not understand at all in the aspect of pronunciation and accent. On the other hand, the 3 point score got the highest percentage in the five aspects of the phase. Students learn from their mistakes in the previous three phases. In this phase, the aspect of fluency shows that most of them were quite capable in speaking even though they still have difficulties and doubts. In the aspect of pronunciation and accent, it also shows that their speech could be understood by their listeners even with nonnative speaker accent. In this phase, there were $1.1 \%$ who got the highest point for the aspect of pronunciation and accent. The students pronounce words correctly by imitating certain accents in English. Furthermore, the aspect of vocabulary scored a 3 pint as much as $74.2 \%$. This phase proves that students made progress in their achievement. Students used correct vocabularies and were quite easy to understand. Only $3.4 \%$ who get 1 point because they do not use correct vocabularies and it is difficult to understand. In this aspect, students get scored 4 point $(0.57 \%)$, in which they use correct variety of vocabularies. The aspect of grammar, the most scored point was 3 by $77.1 \%$ and the remaining were $1(4 \%)$ and $2(5.1 \%)$. The grammar aspect in this phase shows that few students made few grammar mistakes upon speaking. The grammar structure in this phase was variative using two tenses and more. Even though there was a decrease in the percentage of 3 point scores, which was only $66.8 \%$. The aspect of details of information increases at 4 pooint score $(20.5 \%)$. Students were fairly straightforward in providing detailed information in this phase. They have also provided main and additional information clearly for their listeners, although some of them get 1 and 2 point by $4 \%$ and $5.1 \%$ respectively. They were still lacking in providing the main and additional information.

Based on these research results, it is concluded that the implementation of portfolio assessment for UNNES students' English speaking ability has a positive impression on students in correcting their errors during the learning process. Portfolio assessment is also proven very effective for improving UNNES students' English speaking ability. Portfolio assessment also increases students' motivation, confidence, participation, and attention during the learning process. Portfolio assessment is also potential to improve lecturers'learning management, especially during assessment.

\section{References}

[1], [3], [5] , [8] Mahardika, B. 2018. Penerapan metode penilaian berbasis portofolio dalam meningkatkan pembelajaran bahasa Indonesia. Elementary, 4, 33-46.

Arifin, Z. 2010. Penilaian Portfolio (Konsep, Prinsip, Prosedur). Universitas Pendidikan Indonesia. 
[4] Hadiyaturrido, Lasmawan, I. W., \& Marhaeni, A. A. I. N. 2013. Pengaruh metode penilaian portofolio dalam pembelajaran terhadap motivasi belajar dan prestasi belajar IPS. eJournal Program Pascasarjana Universitas Pendidikan Ganesha, 3

[6] Creswell, J. W., \& Poth, C. N. Qualitative inquiry and research design: Choosing among five approaches. Sage publications. 2016. 76.

[7] Milles, B. M., \& Huberman, M. A. Analisis Data Kualitatif. 1992. 16-19.

[9] Khampusaen, D., \& Un, J. L. 2018. The effect of electronic speaking portfolios on EFL learners' speaking ability. ISERD International Conference, 1-8.

[10] Yastibas, A. E., Cepik, s. 2014. Teachers' attitude toward the use of e-portfolio in speaking classes in English language teaching and learning. Social and Behavioral Science, 176, 514-525. Retrieved on 26 October 2020 from (http://creativecommons.org/licenses/by-nc-nd/4.0/).

[11] Demirel, M., \& Duman, H. (2015). The use of portfolio in English language teaching and its effects on achievement and attitude. Procedia-Social and behavioral sciences, 191, 2634-2640.

[12], [13] Tekir, S. 2020. Speaking portfolio/audio-visual portfolio: an alternative way of speaking assessment. Studies in Subject Specific Education, 63-77. Retrieved from on 26 October, 2020 from https://www.researchgate.net/publication/339988069

[14] Huang, J. (2012). The implementation of portfolio assessment in integrated English course. English Language and Literature Studies, 2(4), 15. 